\title{
LPG - mieszanina propan-butan - aspekty normalizacyjne
}

\begin{abstract}
W artykule przedstawiono podstawowe dane dotyczące mieszaniny propan-butan LPG (Liquefied Petroleum Gas): zastosowanie, strukturę rynku LPG w Polsce, pochodzenie i skład. Omówiono różnice w wymaganiach w zależności od zastosowania LPG: do celów grzewczych i jako paliwo do silników samochodowych. Przedstawiono krajowe normy dotyczące LPG: PN-C-96008:1998 Przetwory naftowe - Gazy węlowodorowe - Gazy skroplone $C_{3}-C_{4}$, PN-C-96000:1982 Przetwory naftowe - Gazy weglowodorowe - Gazy skroplone $C_{3}-C_{4}$, normy międzynarodowe ISO (International Organization for Standardization) oraz zagraniczne normy własne BS (British Standard) i DIN (Deutsches Institut für Normung). Przedstawiono prace nad normą europejską EN 589 Automotive fuels - LPG - Requirements and test methods w Europejskim Komitecie Normalizacyjnym CEN (European Committee for Standardization), prowadzone w Grupie Roboczej CEN/TC19/WG23 Specification of automotive LPG and related test metod oraz prace nad jej polską wersją PN-EN 589 Paliwa do pojazdów samochodowych - LPG - Wymagania i metody badań prowadzone w PKN (Polski Komitet Normalizacyjny), odpowiednio w Podkomitecie PKN/KT222/PK1 ds. Paliw Płynnych. Zaprezentowano szczegółową analizę zmian wprowadzonych w ostatniej wersji EN 589:2008 + A1:2012 Automotive fuels - LPG - Requirements and test methods w odniesieniu do EN 589:2008, w szczególności weryfikację parametrów jakościowych oraz zmiany w powołanych metodach badawczych. Zwrócono uwagę na znaczenie normalizacji europejskiej i krajowej dla jakości LPG stosowanego do zasilania nowoczesnych silników.
\end{abstract}

Słowa kluczowe: LPG, normalizacja, procedury CEN i PKN.

\section{LPG - propane-butane mixture - standardization aspects}

The article presents basic data on propane-butane LPG (Liquefied Petroleum Gas): the structure of the LPG market in Poland, the origin and composition. Discusses differences in the requirements, depending on the use of LPG: for heating purposes and as a fuel for vehicles. Presents Polish national standards for LPG: PN-C-96008:1998 Przetwory naftowe Gazy węglowodorowe - Gazy skroplone $C_{3}-C_{4}$, PN-C-96000:1982 Przetwory naftowe - Gazy węglowodorowe - Gazy skroplone $C_{3}-C_{4}$ also international standards ISO (International Organization for Standardization) and foreign national standards BS (British Standard) and DIN (Deutsches Institut für Normung). Presents the work on European standard EN 589 Automotive fuels - LPG-Requirements and test methods in the European Committee for Standardization (CEN) being carried out within Work Group CEN/TC19/WG23 Specification of automotive LPG and related test metods well as work on its Polish version PN-EN 589 + A1:2012 Paliwa do pojazdów samochodowych - LPG - Wymagania i metody badań in the Polish Committee for Standardization (PKN) within the Subcommittee PKN/KT222/PK1 Liquid fuels. A detailed analysis of the changes introduced in the last version of EN 589:2008 + A1:2012 Automotive fuels - LPG Requirements and test methods relating to EN 589:2008 particularly verification of quality parameters and changes in the referenced test methods standards is presented. The importance of European and national standardization for the quality of the LPG used to power modern engines is highlighted.

Key words: LPG, standardization, CEN and PKN procedures.

\section{Wstęp}

Mieszanina skroplonych gazów węglowodorowych, głównie propanu i butanu, określana akronimem LPG (Liquefied
Petroleum Gas), jest produktem dość powszechnie stosowanym na świecie. Gaz płynny oraz propan-butan to alternatywne 
nazwy dla tego produktu. Węglowodory te są pozyskiwane podczas wydobywania ropy naftowej i gazu ziemnego oraz przerobu ropy naftowej; możliwe jest także otrzymywanie ich ze źródeł odnawialnych. Zastosowanie LPG jest bardzo zróżnicowane, począwszy od wykorzystania tego produktu jako paliwa do silników samochodów z zapłonem iskrowym, a także jako paliwa do celów grzewczych, aż do zastosowań przemysłowych, w tym jako surowca do syntez chemicznych. W Polsce w 2015 roku sprzedano 2245 tys. ton tego paliwa (wzrost o $2 \%$ w stosunku do konsumpcji z roku 2014), z czego $16,7 \%$ pochodziło z produkcji krajowej. Główne kierunki importu to Rosja (998 tys. ton), Kazachstan (405 tys. ton) i Białoruś (195 tys. ton); dane ilościowe dotyczą 11 miesięcy 2015 r. Strukturę sprzedaży LPG na polskim rynku przedstawiono na rysunku 1.

$\mathrm{Z}$ danych przedstawionych na rysunku 1 wynika, że głównymi odbiorcami mieszaniny propan-butan w Polsce są użytkownicy samochodów. Struktura zużycia LPG w Polsce będzie warunkowała wymagania jakościowe stawiane temu produktowi.

Powszechnie uważa się, że LPG jest mieszaniną dwóch składników: propanu i butanu, w proporcjach 50:50 lub 40:60/60:40. Tymczasem LPG może stanowić mieszaninę nawet do kilkunastu węglowodorów i także zawierać inne związku chemiczne, stanowiące zanieczyszczenia [1, 2], które

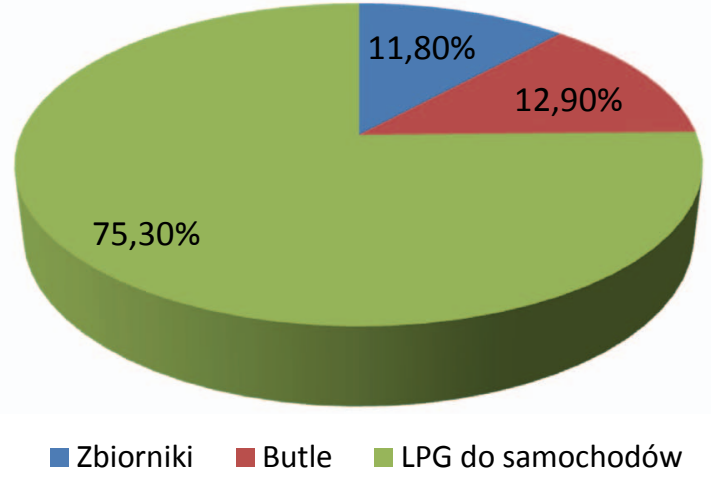

Rys. 1. Struktura rynku LPG w Polsce w 2015 r. [14]

negatywnie wpływają na właściwości użytkowe mieszaniny propan-butan. W zależności od przeznaczenia gazu płynnego ich obecność może mieć mniejszą lub większą wagę. Jak wspomniano powyżej, LPG to nie tylko mieszanina dwóch węglowodorów: propanu i butanów (izobutanu, n-butanu), ale także wielu innych węglowodorów, zarówno lżejszych, jak i cięższych od głównych składników. Ich udział w LPG uzyskanym podczas przeróbki ropy naftowej w rafinerii zależy od składu komponentowego tego paliwa. Komponenty LPG charakteryzują się dużym zakresem zmienności składu, a co za tym idzie - także właściwości, co ma odzwierciedlenie w jakości finalnego produktu [14].

\section{Normy produktowe dla mieszaniny propan-butan}

Jak już wspomniano we wstępie, mieszanina węglowodorów, głównie o trzech i czterech atomach węgla w łańcuchu, może być wykorzystywana do różnych celów, co warunkuje określone wymagania jakościowe dla danego produktu. $\mathrm{Z}$ tego powodu przed normalizacją (nie tylko krajową, ale również europejską i światową) stoi bardzo poważne zadanie, aby opracować we właściwy sposób normy produktowe, czyli uwzględnić potencjalne zagrożenie jakości, jak również wagę tego zagrożenia ze względu na zastosowanie LPG. Mając na uwadze powyższe, dla mieszaniny propan-butan obowiązują różne normy w zależności od przeznaczenia tego produktu.

Powszechnym zastosowaniem mieszaniny propan-butan jest wykorzystanie jej do celów grzewczych. Używana jest ona zarówno w przydomowych instalacjach centralnego ogrzewania, jak również w instalacjach przemysłowych - tam, gdzie nie ma sieci gazu ziemnego, a także w kuchenkach gazowych gospodarstw domowych. Mieszanina ta może stanowić również surowiec do syntez i procesów chemicznych, a także komponent do benzyny silnikowej jako frakcja butanowa. W Polsce aktualną specyfikacją, ujmującą te zagadnienia, jest norma PN-C-96008:1998
Przetwory naftowe - Gazy weglowodorowe - Gazy skroplone C3-C4. Ukazując się w 1998 roku, zastąpiła ona częściowo normę PN-C-96000:1982 Przetwory naftowe. Gazy węglowodorowe - Gazy skroplone $\mathrm{C}_{3}-\mathrm{C}_{4}-\mathrm{w}$ zakresie ,podstawowy surowiec do dalszej przeróbki chemicznej, również jako gaz opałowy dla gospodarstw domowych, przemysłu i turystyki (...) z wyjątkiem przeznaczenia jako paliwo do silników spalinowych" [21]. Istotnymi zmianami w dokumencie PN-C-96008:1998, w stosunku do zastępowanej normy PN-C-96000:1982 Przetwory naftowe - Gazy weglowodorowe (płynne $C_{3}-C_{4}$ ), są: określenie wymagań dla poszczególnych rodzajów gazów skroplonych $\mathrm{C}_{3}-\mathrm{C}_{4}$, ujednolicenie metod badań, wprowadzenie wzoru atestu na gazy skroplone. Zgodnie z tą specyfikacją, w zależności od zawartości głównych węglowodorów, rozróżnia się trzy rodzaje gazów skroplonych [20]. Z kolei częściowo zastąpiona norma PN-C-96000:1982, która odnosiła się jedynie do gazów węglowodorowych przeznaczonych jako paliwo do silników spalinowych, została wycofana z dniem 15 listopada 2012 roku w wyniku systematycznego przeglądu przeprowadzonego przez Polski Komitet Normalizacyjny (PKN). Zgodnie z procedurami $\mathrm{PKN}$ normy poddawane są weryfikacji - sys- 
tematycznemu przeglądowi co 5 lat. Jeżeli nie zostanie podjęta decyzja o nowelizacji normy, zostanie ona uznana za nieaktualną i wycofana. Wynika to z procedur PKN, zgodnie z którymi normy sprzed roku 1994 nie mogą uzyskać statusu norm aktualnych; przeznaczone są ,,do nowelizacji’ lub „do wycofania” [12].

Norma PN-C-96008 nie ma odpowiedników wśród norm międzynarodowych, natomiast poszczególne państwa wprowadziły własne specyfikacje krajowe dla LPG. Brytyjska norma BS 4250 Specification for commercial butane and commercial propane podaje wymagania dla handlowego propanu-butanu, które mają być spełnione przez producentów i dystrybutorów. Obejmuje ona wytyczne dotyczące składu chemicznego, ciśnienia par i korozji. Zawiera również wymagania związane z bezpieczeństwem, w tym dotyczące: narażenia zdrowia, zapachu, zawartości $\mathrm{H}_{2} \mathrm{~S}$ i oblodzenia zaworów. Wytyczne w najnowszym wydaniu normy BS 4250 zostały skorelowane z warunkami zawartymi w normie BS-EN 589 dla LPG stosowanego jako paliwo do silników samochodowych, gdyż propan produkowany jest również pod kątem spełnienia wymagań obu specyfikacji. Przy czym norma BS 4250 ma szerszy zakres, ponieważ obejmuje zarówno produkt przeznaczony do celów domowych, grzewczych i przemysłowych, jak i do zastosowania jako paliwo do silników samochodowych [6]. Obowiązującą obecnie niemiecką normą jest DIN 51622:1985 Liquefied petroleum gases; propane, propene, butane, butene and their mixtures; requirements [8]. Określa ona minimalne wymagania dla skroplonych gazów węglowodorowych (LPG), w szczególności dotyczące ich składu i czystości. Normę stosuje się do propanu, propenu, butanu, butenu i ich mieszanin pochodzących z procesów przerobu ropy naftowej $\mathrm{i}$ innych procesów petrochemicznych. Wykorzystywane są one jako surowiec do procesów chemicznych i jako paliwo dla gospodarstw domowych, w handlu i przemyśle, a także w silnikach spalinowych pojazdów; są również komponentem gazu miejskiego [3].

Międzynarodowa organizacja normalizacyjna ISO ujmuje tematykę LPG w wydanych przez siebie standardach:

- ISO 8216-3:1987 Petroleum products - Fuels (classF) - Classification - Part 3: Family L (Liquefied petroleum gases); ostatnia rewizja tej normy została przeprowadzona przez ISO w roku 2015, w ramach systematycznego przeglądu norm; tym samym norma została uznana za aktualną;

- ISO 9162:2013 Petroleum products - Fuels (class F) Liquefied petroleum gases - Specifications [11];

- w normie klasyfikacyjnej (ISO 8216-3:1987) podano podział LPG na dwie kategorie:
- ISO-F-LP (produkt węglowodorowy składający się głównie z propanu i/lub propenu),

- ISO-F-LB (produkt węglowodorowy składający się głównie z butanu i/lub butenu) [18];

- w normie produktowej (ISO 9162:2013) zawarte zostały wymagania dla handlowego propanu i butanu [19].

Specyfikacje te nie odnosza się do zastosowania gazu płynnego jako paliwa do pojazdów samochodowych. Zgodnie z zapisem w ISO 9162:2013 (punkt 1.1 Zakres) norma ta: „nie jest przeznaczona do wprowadzania, ani nie ma zastąpić zapisów bądź wpływać na zapisy w odpowiednich normach krajowych, ponieważ każdy kraj podlega innym przepisom, stosuje inne przepisy dotyczące bezpieczeństwa, ma własne rozwiązania branżowe i rynkowe (...)" [19]. Mimo iż norma ISO na gaz płynny jest dokumentem o światowym zasięgu, postanowienia w niej zawarte nie muszą wpływać w bezpośredni sposób na zapisy w normach krajowych [4].

Inaczej przedstawia się sytuacja w przypadku norm europejskich (EN). Europejski Komitet Normalizacyjny CEN European Committee for Standardization zrzesza krajowe jednostki normalizacyjne państw Unii Europejskiej. Z dniem 1 stycznia 2004 roku PKN, jako polska krajowa jednostka normalizacyjna, otrzymał status pełnego członkostwa w CEN. PKN ma prawo uczestnictwa we wszystkich organach na równych prawach z innymi członkami. Obowiązkiem wynikającym z członkostwa jest stosowanie się do Przepisów Wewnętrznych CEN/CENELEC. Określają one m.in. zasady wprowadzania norm europejskich do krajowego zbioru norm [23]. W ciągu 6 miesięcy od ukazania się normy EN państwa członkowskie CEN mają obowiązek opublikowania identycznej normy krajowej i wycofania norm sprzecznych (np. poprzedniego wydania danej normy $\mathrm{w}$ języku polskim). Zgodnie z procedurami PKN realizuje się to w ten sposób, że norma EN jest najpierw uznawana w języku oryginału, następnie powstaje norma PN-EN z polskim tytułem w angielskiej wersji językowej. Po uznaniu normy EN za PN-EN można przystapić do procedury wprowadzania polskiej wersji normy [5]. W PKN tematyka LPG umiejscowiona jest w Podkomitecie ds. Paliw Płynnych PK1 Komitetu Technicznego KT222 ds. Przetworów Naftowych i Cieczy Eksploatacyjnych, którego Sekretariat prowadzi Instytut Nafty i Gazu - Państwowy Instytut Badawczy [12].

W związku z powyższym, aktualna polska norma PN-EN 589+A1:2012 Paliwa do pojazdów samochodowych - LPG - Wymagania i metody badań, wprowadzająca EN 589:2008+A1:2012, ma dwie wersje o tym samym tytule i numerze: angielską, która ukazała się 4 maja 2012 roku, i polską z 29 marca 2013 roku. Dokumenty te są wersjami językowymi tej samej normy i mają status dokumentów identycznych [12]. 


\section{Propan-butan jako paliwo do silników samochodowych}

Najbardziej popularnym w Polsce zastosowaniem LPG jest zasilanie samochodów osobowych z zapłonem iskrowym. Początki tzw. ,autogazu” w Polsce sięgają pierwszej połowy lat dziewięćdziesiątych ubiegłego wieku. Wtedy był on postrzegany jako tanie paliwo, raczej do starych modeli samochodów osobowych. Ówcześnie jakość LPG, będącego paliwem do samochodów, określała wspomniana norma PN-C-96000:1982. Wraz z rozwojem systemów zasilania gazem płynnym nastąpiła intensyfikacja prac normalizacyjnych w tym zakresie.

W Europie w 2000 roku po raz pierwszy ukazała się norma dedykowana LPG jako paliwu do silników samochodowych EN 589:2000 Automotive fuels - LPG - Requirements and test methods [16]. W przeciągu szesnastu lat była kilkakrotnie aktualizowana. Ostatnia zmiana miała miejsce w 2012 roku ukazała się norma skonsolidowana EN 589:2008+A1:2012 z wprowadzonymi do tekstu zmianami [9]. Oprócz aktualizacji metod badań, w wyniku prac oraz doświadczeń jednostek naukowo-badawczych i przemysłu, został zweryfikowany zakres parametrów jakościowych. Obecne wydanie normy, w stosunku do pierwszego, w zakresie parametrów jakościowych różni się następującymi elementami:

- obniżono dopuszczalną zawartość siarki ze $100 \mathrm{mg} / \mathrm{kg}$ do $50 \mathrm{mg} / \mathrm{kg}$,

- obniżono dopuszczalną pozostałość po odparowaniu ze $100 \mathrm{mg} / \mathrm{kg}$ do $60 \mathrm{mg} / \mathrm{kg}$,

- zrezygnowano z parametru „zawartość metanolu”.

Kilka istotnych zmian wprowadzono również w zakresie metod badań. Do najważniejszych z nich należą:

- rezygnacja z metody Wickbolda do oznaczania zawartości siarki EN 24260 (jest to ostatnio wprowadzona zmiana),

- rezygnacja z wysokotemperaturowej metody oznaczania pozostałości po odparowaniu (EN ISO 13757) na rzecz wysokotemperaturowej metody grawimetrycznej (EN 15471) oraz metody chromatograficznej (EN 15470) [22].

Rynek pojazdów samochodowych napędzanych LPG jest znaczący, a instalacje zasilane tym paliwem montowane są również w samochodach fabrycznie nowych [1]. Wynika to nie tylko z przyczyn ekonomicznych. LPG ma stosunkowo niski wskaźnik emisji GHG w cyklu życia w porównaniu z innymi paliwami kopalnymi. Według średnich wartości standardowych intensywności emisji gazów cieplarnianych w cyklu życia, podanych w dyrektywie 2015/652 [15], wskaźnik emisji dla LPG wynosi 73,6 g CO $\mathrm{CO}_{2 \mathrm{eq}} / \mathrm{MJ}$, podczas gdy w przypadku benzyny silnikowej uzyskanej z konwencjonalnej ropy naftowej - 93,2 $\mathrm{g} \mathrm{CO}_{2 \mathrm{eq}} / \mathrm{MJ}$, a oleju napędowego - $95 \mathrm{~g} \mathrm{CO}_{2 \mathrm{eq}}$ /MJ. Według przeprowadzonych badań, których wyniki zostały opublikowane [7], zastosowanie LPG w porównaniu $\mathrm{z}$ benzyną silnikową daje niższą emisję $\mathrm{HC}$, $\mathrm{CO}$ i $\mathrm{CO}_{2}$. Natomiast montaż instalacji LPG skutkuje tym, że producent gwarancją obejmuje również zasilanie LPG. Stąd obecnie w CEN (w ramach grupy roboczej CEN/TC19/ WG23 Specification of automotive LPG and related test metod) prowadzone są prace nad aktualizacją wymagań jakościowych normy EN 589 w taki sposób, aby zapewnić, że paliwo spełniające wymagania wspomnianej normy nie powoduje uszkodzeń silnika czy systemów zasilania i oczyszczania spalin. Jak powszechnie wiadomo, siarka powoduje dezaktywację katalizatora oczyszczania spalin i dlatego jej poziom w paliwach (benzynach silnikowych i olejach napędowych) jest ograniczony do $10 \mathrm{mg} / \mathrm{kg}$. Obecnie prowadzone prace w CEN skupiają się wokół dalszego obniżenia limitu zawartości siarki. Dostrzeżono również [10] potrzebę wprowadzenia zmian w parametrze zabezpieczającym właściwości antystukowe paliwa; stosowana obecnie liczba oktanowa motorowa nie zapewnia odpowiedniej korelacji z parametrami pracy silnika. Wprowadzenie właściwego zamiennika wymaga wykonania wielu prac, natomiast z działań przeprowadzonych dotychczas wynika [10], że propan jest składnikiem, którego zawartość poprawia te właściwości paliwa. Dlatego poważnie rozważa się wprowadzenie również parametru zawartość propanu (niezależnie od klasy klimatycznej).

Podsumowując powyższe rozważania, należy podkreślić, że dziś na rynku polskim funkcjonują dwie normy dla mieszaniny propan-butan, w zależności od jej przeznaczenia:

- norma PN-C-96008:1998 dla gazów skroplonych $\mathrm{C}_{3}-\mathrm{C}_{4}$ stosowanych jako: surowiec do dalszej przeróbki chemicznej, gaz opałowy, paliwo oświetleniowe, komponent paliw płynnych [21],

- norma PN-EN 589 + A1:2012 dla gazu będącego paliwem, stosowanym w samochodach z silnikami dostosowanymi do jego użytku [17].

W związku z odmiennym przeznaczeniem produktu, normy te różnią się znacznie zakresem parametrów jakościowych. Różnice te zestawiono w tablicy 1. „+" oznacza, że norma definiuje ten parametr, a ,,-, że nie jest on przywołany.

Analizując dane zawarte w tablicy 1, można zaobserwować, że jedynie parametry: zawartość dienów, siarkowodoru, siarki, wody oraz zapach są wspólne dla obu norm (kolor żółty). Przy czym norma PN-C-96008 ogranicza zawartość dienów do $1 \%$ masowego, a norma PN-EN 589 do $0,5 \%$ molowego.

W normie PN-EN 589 skład węglowodorowy nie jest w sposób bezpośredni ograniczony (wiersz $1 \mathrm{w}$ tablicy 1), więc z pozoru wydaje się, że LPG do zasilania silników samochodowych może charakteryzować się dowolną zawartością węglowodorów $\mathrm{C}_{3}-\mathrm{C}_{4}$. Teoretycznie jest to zdanie praw- 
Tablica 1. Zakres parametrów jakościowych według norm PN-C-96008 i PN-EN 589

\begin{tabular}{|c|l|c|c|}
\hline \multicolumn{1}{|c|}{ Parametr } & \multicolumn{1}{|c|}{$\begin{array}{c}\text { Norma } \\
\text { PN-C-96008:1998 }\end{array}$} & $\begin{array}{c}\text { Norma } \\
\text { PN-EN 589+A1:2012 }\end{array}$ \\
\hline 1. & \multicolumn{1}{|c|}{ Zawartość węglowodorów $\left(\mathrm{C}_{1}-\mathrm{C}_{5}\right)$} & + & - \\
\hline 2. & Liczba oktanowa motorowa & - & + \\
\hline 3. & Zawartość dienów & + & + \\
\hline 4. & Siarkowodór & + & + \\
\hline 5. & Zawartość siarki & + & - \\
\hline 6. & Zawartość oleju mineralnego & - & + \\
\hline 7. & Pozostałość po odparowaniu & + \\
\hline 8. & Zawartość wody & + & - \\
\hline 9. & Amoniak & + & + \\
\hline 10. & Zapach & + & - \\
\hline 11. & Wartość opałowa & + & + \\
\hline 12. & Gęstość & + & - \\
\hline 13. & Prężność par absolutna w temperaturze: $-15^{\circ} \mathrm{C}, 40^{\circ} \mathrm{C}, 70^{\circ} \mathrm{C}$ & - & - \\
\hline 14. & Względna prężność par w temperaturze $40^{\circ} \mathrm{C}$ & - & + \\
\hline 15. & $\begin{array}{l}\text { Minimalna temperatura, w której względna prężność par jest nie } \\
\text { mniejsza niż } 150 \text { kPa }\end{array}$ & - & + \\
\hline 16. & Badanie działania korodującego na płytce miedzianej & + \\
\hline
\end{tabular}

dziwe; specyfikacja nie ogranicza zawartości ani propanu, ani butanu, ani innych węglowodorów w sposób bezpośredni. Natomiast w rzeczywistości udział ten jest ograniczony w sposób pośredni. Paliwo LPG musi charakteryzować się odpowiednią liczbą oktanową motorową czy względną prężnością par, a wielkość tych parametrów wynika bezpośrednio z udziału poszczególnych węglowodorów. Zadaniem technologa jest tak dobrać skład komponentowy paliwa, aby spełniało ono wymagania specyfikacji [14]. Norma PN-EN 589 zawiera parametry istotne z punktu widzenia eksploatacji pojazdu: liczbę oktanową motorową (odpowiedzialną za spalanie stukowe), względną prężność par w $40^{\circ} \mathrm{C}$ (zapewniającą bezpieczeństwo użytkowania), minimalną temperaturę, w której względna prężność par jest nie mniejsza niż $150 \mathrm{kPa}$ (umożliwiającą właściwą pracę układu zasilania) oraz badanie działania korodującego na płytce miedzianej (w celu zabezpieczenia instalacji gazowej przed korozją).

W zależności od zawartości poszczególnych komponentów i wymagań zależnych od warunków klimatycznych, dana mieszanina gazów skroplonych może spełniać wymagania obu norm lub tylko jednej z nich - realizacja wytycznych jednej specyfikacji nie wyklucza wypełnienia wymagań drugiej. Dlatego też bardzo często gaz płynny z jednego zbiornika sprzedawany jest zarówno do celów komunalnych (np. do napełniania butli), jak i jako „autogaz”. Niemniej jednak, w takim przypadku, operator powinien upewnić się, czy sprzedawany produkt spełnia wymagania wspomnianych powyżej specyfikacji.

\section{Podsumowanie}

Ekologiczne i ekonomiczne aspekty stosowania LPG, a co za tym idzie - rozwój systemów zasilania, sprawiają, że dziś coraz częściej „,instalacja gazowa” montowana jest w nowoczesnych samochodach, bardzo często fabrycznie wyposażonych w elektroniczne sterowanie systemów zasilania. Dlatego też jakość oferowanego LPG musi być stale podnoszona. Ogromnym wyzwaniem, stojącym dziś przed normalizacją, zarówno na poziomie europejskim, jak i krajowym, jest okre- ślenie zagrożeń jakości dla LPG stosowanego we współczesnych pojazdach. Wraz z identyfikacją zagrożeń i wprowadzaniem odpowiednich limitów konieczne jest także opracowywanie nowych metod badań, pozwalających przede wszystkim identyfikować zagrożenie, ale również takich, które dostarczają dodatkowych informacji o charakterze zanieczyszczenia. Będzie to miało szczególne znaczenie, gdy na rynku pojawi się LPG pochodzenia biologicznego. 
Artykuł powstał na podstawie pracy INiG - PIB pt. Podstawy merytoryczne dostosowania norm polskich z zakresu ropy i gazu do wymagań UE; nr zlecenia: 88/TN/DN/2016/01; nr archiwalny: DK-5100-95/16.

\section{Literatura}

[1] Altkorn B.: Wplyw zanieczyszczeń LPG na jego jakość. Nafta-Gaz 2009, nr 12, s. 998-1005.

[2] Altkorn B.: Źródta zanieczyszczeń w paliwie LPG II. Konferencja Naukowo-Techniczna - VII Forum Dyskusyjne Sekcji POLLAB-PETROL, Kraków 3-5.11.2010.

[3] American National Standards Institute; http://webstore.ansi.org (dostęp: lipiec 2016).

[4] Błaszkiewicz Z.: Normalizacja LPG $i C_{3}-C_{4}$. Nafta-Gaz 2011, nr 11, s. 837-844.

[5] Błaszkiewicz Z.: Zmiany w procedurach normalizacyjnych - numeracja Polskich Norm i czwarta wersja językowa Normy Europejskiej. Nafta-Gaz 2014, nr 10, s. 728-733.

[6] British Standards Institution; http://shop.bsigroup.com (dostęp: lipiec 2016).

[7] Can Çinar, Fatih Sahin, Özer Can, Ahmet Uyumaz: A comparison of performance and exhaust emissions with different valve lift profiles between gasoline and LPG fuels in a SI engine. Applied Thermal Engineering 2016, vol. 107, s. $1261-1268$.

[8] Deutsches Institut für Normung; http://www.din.de (dostęp: lipiec 2016).

[9] European Committee for Standardization; https://www.cen.eu (dostęp: lipiec 2016).

[10] Informacje własne z prac Grupy Roboczej CEN/TC19/WG23.

[11] International Organization for Standardization; http://www. iso.org (dostęp: lipiec 2016).

[12] Polski Komitet Normalizacyjny; http://www.pkn.pl (dostęp: lipiec 2016);

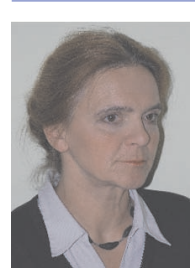

Mgr inż. Zofia BŁASZKIEWICZ

Starszy specjalista badawczo-techniczny;

kierownik Zakładu Normalizacji.

Instytut Nafty i Gazu - Państwowy Instytut Badawczy

ul. Lubicz 25 A

31-503 Kraków

E-mail: zofia.blaszkiewicz@inig.pl
[13] Raport Roczny 2015 Polskiej Organizacji Gazu Ptynnego. Polska Organizacja Gazu Płynnego, Warszawa 2016.

[14] Rogowska D., Pałuchowska M.: Wpływ właściwości komponentów gazu skroplonego LPG na jakość produktu finalnego. Nafta-Gaz 2009, nr 8, s. 617-623.

\section{Akty prawne i normatywne}

[15] Dyrektywa Rady (UE) 2015/652 z dnia 20 kwietnia 2015 r. ustanawiajaca metody obliczania $i$ wymogi $w$ zakresie sprawozdawczości zgodnie z dyrektywa 98/70/WE Parlamentu Europejskiego i Rady odnoszaca się do jakości benzyny i olejów napędowych. Dziennik Urzędowy Unii Europejskiej L107/26.

[16] EN 589:2000 Automotive fuels - LPG - Requirements and test methods.

[17] EN 589:2008 + A1:2012 Automotive fuels - LPG - Requirements and test methods.

[18] ISO 8216-3:1987 Petroleum products - Fuels (classF) - Classification - Part 3: Family L (Liquefied petroleum gases).

[19] ISO 9162:2013 Petroleum products - Fuels (class F) - Liquefied petroleum gases - Specifications.

[20] PN-C-96000:1982 Przetwory naftowe - Gazy węglowodorowe (ptynne $\left.C_{3}-C_{4}\right)$.

[21] PN-C-96008:1998 Przetwory naftowe - Gazy węglowodorowe - Gazy skroplone $C_{3}-C_{4}$.

[22] PN-EN 589 + A1:2012 Paliwa do pojazdów samochodowych - LPG - Wymagania i metody badań.

[23] Przepisy Wewnętrzne CEN/CENELEC, cześć 2, p. 11.2.6. Obowiąki; http://www.pkn.pl (dostęp: lipiec 2016).

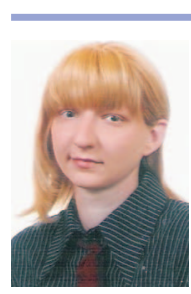

Mgr inż. Delfina ROGOWSKA

Starszy specjalista badawczo-techniczny, zastępca kierownika Zakładu Paliw i Procesów Katalitycznych. Instytut Nafty i Gazu - Państwowy Instytut Badawczy ul. Lubicz 25 A

31-503 Kraków

E-mail: delfina.rogowska@inig.pl 